\title{
Chapter 11: \\ Criminal law protection of wildlife reserves in Cameroon
}

Marie Ngo Nonga

\section{Introduction}

Given its privileged geographical situation, nearly $92 \%$ of Africa's ecosystems are represented in Cameroon. It is, therefore, a country that is very rich in biodiversity. However, these biological resources are abundantly exploited both by the state and by the local populations, which have many of their activities primarily focused on the exploitation of natural resources. In fact, despite the legal status of protected areas, ${ }^{1}$ wildlife reserves maintain their nurturing and health functions for the local populations, and the resources they contain are sought after for food, commercial, medicinal and cultural purposes. They highly contribute to the annual revenue of the state of Cameroon.

There are six wildlife reserves situated in different regions of Cameroon: Dja in the south; Douala-Edea and Lake-Ossa in the Littoral; Kimbi and Mbi-crater in the northwest and Santchou in the west. ${ }^{2}$ Wildlife reserves are an integral part of what are commonly called protected areas. They are geographically defined areas managed to achieve specific conservation and sustainable development objectives of a given resource or resources. ${ }^{3} \mathrm{~A}$ wildlife reserve is, therefore, an area set apart for the conservation, development and propagation of wild animal life, as well as for the protection and development of its habitat. Within these reserves, hunting is prohibited unless authorised by administrative authorities, and/or where other human activities are regulated or prohibited. ${ }^{4}$

1 The story of the birth of protected areas around the world began in the American State of Wyoming with the creation of Yellowstone National Park in 1872. On the African continent, the very first area is the Sabie Game Reserve of South Africa which became the Krüger National Park in 1898. In Cameroon, the first protected areas were created on 12 June and 19 November 1932, Mozogo Gokoro and Benue. To date, Cameroon has nearly 20 protected areas, national parks, reserves and sanctuaries, the touristic and eco-touristic assets of which are undeniable.

2 Gonmadje et al. (2015: 48).

3 Article 2 of Decree No. 95/466/PM of 20 July 1995 to lay down the conditions for the implementation of wildlife regulations.

4 Article 2(7) of the same Decree. 
According to the National Environmental Management Programme (NEMP), Cameroon's wildlife has an immense potential of specimens ${ }^{5}$ and is home to nearly half of the protected animal species in Africa. ${ }^{6}$ It also has a varied biological diversity. Despite the exceptional character and legal status conferred on wildlife reserves, their degradation has accelerated in recent years. Cameroon ranks second in the 2013 world ranking by the International Union for Conservation of Nature (IUCN) of countries in which a significant number of major species are threatened, with a total of 260 species at risk.

The causes of degradation of wildlife reserves and their biodiversity are multiple and intrinsically linked to the development of human activities. The first is commercial poaching, aggravated by the frustration and impoverishment of local populations that depend on these resources for their subsistence needs. Secondly, people hunt the rarest animal species and harvest plant species with high market value. ${ }^{7}$ It is also necessary to mention the precarious conditions in which state agents in charge of monitoring wildlife reserves live and which make them particularly vulnerable to corruption and excessive complacency towards poachers.

Furthermore, the insufficient technical and financial capacity of the forest administration is another factor threatening wildlife reserves. They lack modern equipment and watchtowers, which are necessary for viewing and identifying species and especially essential to observing the dynamics of species in order to prevent possible attacks and incursions by hunters.

Finally, the lack of cohesion in the policies relevant to protected area management is another source of their decline. Authorities continue to encourage the harvesting of animals by issuing a high number of licences and hunting permits, notwithstanding the unprecedented extinction of protected species and the subsequent destruction of biodiversity. Most environmental problems observed in wildlife reserves do not stem from the natural vulnerability of the ecosystems, but from the irrational management of these resources. It is, therefore, important to strengthen the effectiveness of the legal framework relevant to protecting wildlife reserves. Cornu's legal vocabulary defines protection as follows: ${ }^{8}$

the precaution which, in response to the need of the person or what it covers, and generally corresponding to a duty for the person ensuring it, consists in protecting a person or good against a risk, in guaranteeing their security and integrity by legal or material means; it designates both the action of protecting and the laid down system of protection (measure, system, arrangement...).

5 PNGE (1996: 87).

6 Tchindjang et al. (2006: 17).

7 In this regard, see Judgement No. 1718/COR of 12 July 2010 of the Douala Court of First Instance against Amiah Awudu, Yeboa Eric and Osei, all three of Ghanaian nationality found guilty of hunting without the necessary hunting licences and permits. 
The protection provided by criminal law, therefore refers to a set of repressive legal means (legal and jurisprudential) adopted by a state or a community to ensure respect for public order in general and specifically for the elements that the law seeks to protect. Criminal law therefore has a key role to play in the environmental policy context, which is strongly imbued with the principle of prevention, insofar as it provides for the imposition of sufficiently dissuasive sanctions on possible offenders. As concerns environmental matters, criminal law, which deals with offences and sentences, ${ }^{9}$ and the laws establishing them, ${ }^{10}$ aims to enact legal and regulatory measures that prevent and sanction biodiversity offences. It thus covers a heterogeneous set of norms from parliament, government or international agreements. These are measures that address biodiversity protection, deal with offences and sanctions, and regulate the conservation, sustainable use or exploitation of biological resources and the fair and equitable sharing of benefits that stem from the use of genetic resources. ${ }^{11}$

The biological diversity, ${ }^{12}$ or variability of living organisms of all origins (individuals and populations $)^{13}$ and the ecological complexes of which they are part, includes diversity among species and between species and ecosystems. ${ }^{14}$ According to the Convention of Biological Diversity (CBD), biodiversity includes landscape diversity including an ecological ${ }^{15}$ or cultural ${ }^{16}$ sense of a given region.

However, this chapter focuses on protecting biodiversity in wildlife reserves through criminal law measures. The level of protection of different species depends on whether they are fully or partially protected. Section 2(8)(a) of Decree No. 95/PM/466 of 20 July 1995 lays down conditions for the implementation of wildlife regulations, underlining the preservation of endangered animal, plant and habitat species. This chapter, therefore, focuses only on "protected" threatened plant and animal species as well as the environment and habitats necessary for the life of these species.

\section{Trousse (1956).}

10 Haus (1873: 1).

11 Article 1 of the Convention on Biological Diversity.

12 Biodiversity, comes from the Greek word "bios" that means "life" or from Latin word "diversitas" which is the contraction of the biology diversity concept. However, the use of the term in its contracted form is from the biologist Wilson following a presentation in 1985, see $<$ http://www.gnis.fr/index/action/page/id/233/title/> (accessed 12-7-2018).

13 De Sadeleer \& Born (2004: 17).

14 Article 2 of the Convention on Biological Diversity. Ecosystem diversity refers to different habitats or environments that exist on earth like tropical or temperate forests, hot or cold deserts, wetlands, lakes, mountains, shrub steppes, and coral reefs.

15 In the ecological sense, the landscape refers to a portion of heterogeneous territory composed of interrelated sets of ecosystems, and is characterised by geomorphological and climatic constants.

16 A cultural landscape refers to a topographically defined territory whose aspect results from the combined action between the nature and man. Defined by the World Heritage Committee (No. 231), it refers to Category V of protected areas. 
Today, environmental protection appears as an imperative towards which many policies ${ }^{17}$ must converge in order to ensure their effectiveness. ${ }^{18}$ From this point of view, criminal law seems to be an essential tool, at least when the sanctions it enacts are both dissuasive and proportionate in the protection of biodiversity. Environmental offences may be subject to both criminal and administrative sanctions. In fact, the Forestry Law of 1994 allows the administrative agents to impose sanctions against perpetrators of offences in the wildlife reserves and apply transactional fines with the authorisation of the State Counsel. These administrative and criminal sanctions have a punitive and restorative aim. This implies the possibility of imposing administrative fines for all environmental offences. In Cameroon, these administrative sanctions are implemented, not alongside criminal sanctions, but often in their stead. This is sometimes ambiguous because they mask the legibility and coherence of environmental policies. In this respect, the effectiveness of these sanctions in deterring prohibited conduct may be questioned, especially since criminal sanctions have a reputation of being ineffective, and even inappropriate. ${ }^{19}$

The perceptible contrast between criminal provisions and the persistence, or even aggravation, of environmental problems they are supposed to solve, raises the question of the role of criminal law in promoting sustainability. While the author partially agrees with the doctrine ${ }^{20}$ linking this ineffectiveness to the disregard for local customs and practices, the fact remains that this ineffectiveness is primarily dependent on the very nature of repressive provisions that protect wildlife reserves in Cameroon, and especially their lax application by courts. Beyond the subjectivity of judgements concerning the state of criminal law, ${ }^{21}$ legislative drafting today should look for a more rigorous approach taking into account the forms and causes of damages to the environment.

If the protection of certain aspects of forest biodiversity has already been examined in some works ${ }^{22}$ in Cameroon, very few consider it in relation to the legal value of protected property. ${ }^{23}$ Yet this vision would not only set the limits of criminal law protection but also guide the choice of the most adequate incrimination technique to ensure appropriate protection of biodiversity. Thus, the construction of incriminations as concerns environmental questions should, as a matter of priority, take into consideration biodiversity as a preserved social value, disconnected from all the links with human interests, while totally integrating man in everything that makes up the environment. This conception implies a global vision of biodiversity that promotes both the

18 We speak of effectiveness when the law enforcement bodies apply the criminal sanction.

19 Fossier (2017: 1).

20 Nguiffo \& Talla (2010: 61).

21 Albertini (2015: 331).

22 Nguiffo (2001); Triplet (2009: 7); Bille \& Picard (2007: 27); and WafoTabopba (2008: 9).

23 D'Ambrosio (2015: 90). 
analysis of species and their habitat and which would include local residents as potential victims of the degradation of their living environment. The destruction of biodiversity has repercussions on all living things and necessarily affects the quality of life of humans, their health, feeding and that of their children, etc. With the disappearance of medicinal and consumable species, the first victims of destruction are the local residents who see their livelihoods becoming scarce ${ }^{24}$ and their fundamental right ${ }^{25}$ to a concrete and visible ${ }^{26}$ quality environment violated.

The putting in place of a criminal policy in the domain of wildlife reserve management in Cameroon is at the heart of the dialectic between the will to preserve ecological balance and the generally preeminent desire to, in no way, disrupt the development of economic activities. This is surely what justifies the contrasted application of existing repressive norms.

A textual application of the criminal law protection of biodiversity in the wildlife reserves of Cameroon

The violation of the standards regulating use, exploitation and management of fauna resources within the protected areas is criminally punishable even if these standards remain bound to administrative law. ${ }^{27}$ This category of administrative sanctions is apprehended more widely as one applied by the public administration. ${ }^{28}$ The essential of the definition of the offence is dictated by administrative authorities and supplemented by an external definition. ${ }^{29}$ In this respect, for the wrongful conduct to be sanctioned, it must necessarily be cumulated with non-compliance with an administrative regulation. ${ }^{30}$ These sanctions are mainly aimed at protecting endangered animal species and secondarily at protecting the surrounding biodiversity.

24 Thus considered, it seems interesting to raise the awareness of local communities on the urgency and importance of their participation to the improvement of their condition, since it is up to them to gather all the necessary efforts to maintain and increase the productivity of protected species by adopting sustainable management methods.

25 Prieur (2003). The fundamental right to a quality environment refers to "the right for everyone to live in a balanced and healthy environment". This is an absolute necessity for Man whose existence on earth as well as the development goals seem seriously compromised by human activities.

26 Prieur (2005: 1160).

27 Ost (1995: 287).

28 Perrier (2017: 1).

29 Estupinal-Silva (2015: 66).

30 Deffairi (2016: 176). 


\subsection{An increased criminal law protection of endangered species}

The Cameroonian legislator has chosen to map out geographic areas regulating access to and use of their resources. This technique is favourable for the survival of wildlife species and their development in their natural habitat. ${ }^{31}$ This involves reserving part of the public domain by enacting police regulations in order to prevent damages to biodiversity $^{32}$ and, in certain cases, to reduce the sometimes irreversible ${ }^{33}$ pressure exerted by individuals on nature. With the creation of wildlife reserves, the legislator was more interested in things - in this case the endangered wildlife - that are not yet "patrimonialised"34 or individualised in a certain manner, but that can be dynamic and/or changing. That is why the legislator has resorted to criminal sanctions as a guarantee for the application ${ }^{35}$ of environmental standards.

The criminal norms for protecting the fauna are contained in various texts. ${ }^{36}$ They criminalise behaviours that violate administrative and regulatory provisions related to the environment. In this respect, the law establishes a set of actions that are subject to strict prohibition or regulation, the violation of which becomes an offence; but as a general rule, it can be seen that the administrative authorities have the power to impose pecuniary sanctions in any case, to sanction either the lack of authorisation to hunt or the non-compliance to applicable rules. ${ }^{37}$ It is for this reason that the company Saf Bois was sentenced to pay a fine of 3,980,000 FCFA for exploiting the national estate without authorisation. ${ }^{38}$

Traditional hunting is the only form of hunting that is carried out without a licence as long as it remains non-commercial. This right was acquired since colonial times ${ }^{39}$ and concerns rodents, small reptiles, birds and other animals of Class C. ${ }^{40}$ However, in order to limit its degrading effects ${ }^{41}$ on biodiversity, it was regulated and limited to

31 Ly \& Ngaide (2008: 89).

32 Martin (1995: 135); Martin (1992: 11); and Clay (2003: 1489).

33 For a research, see Fritz-Legendre (1998: 96); and Cans \& de Klemm (1998: 119).

34 Tricot (2015: 145).

35 Beccaria (1856: 57).

36 Finally, hunting without prior authorisation of wildlife species classified on lists B and C which contain animals open to hunting is totally prohibited in accordance with the provisions of Section 15 of Decree No. 95/466/PM. Section 85 of the framework law of 5 August 1996 on the environment extends the competence of environmental sanctions to the Penal Code and to specific laws applicable to environmental protection.

37 Bush meat is subject to trade, but in addition to the existence of a list of protected animals contained in Order No. 0565/A/MINEF/DFAP/SDF/SRC, administrative authorities condition this activity to the respect of transparency and traceability standards contained in the Washington international convention of 3 March 1973 on the trade in endangered wildlife, ratified on 5 June 1981.

38 Ministry of Forests and Wildlife, press release No. 031/MINFOF/CAB/BNC of 5 July 2005.

39 Kamto (1996: 148).

40 Section 24 paragraph 2 of Decree No. 95/4466/PM.

41 Mafoua (1991: 122). 
the slaughter of authorised games. All other forms of hunting, regardless of the method used, are either prohibited or subject to authorisation. This is the case with sport hunting usually carried out by tourists with weapons authorised by law. ${ }^{42}$

Administrative penalties that can be applied are of various types and levels of severity: they range from the suspension or revocation of the hunting permit or licence to the confiscation of the products harvested, or the restitution and even the injunction for the restoration of the degraded place. ${ }^{43}$ Thus, Section 71(1) of Decree No. 95/466/PM of 20 July 1995 lays down the conditions for the implementation of wildlife regulations providing that the approval given to an operator can be suspended or withdrawn by the administrative authorities and suspension is pronounced in case of recidivism. ${ }^{44}$ In this case, it is no longer the lack of authorisation, but the non-compliance with the rules governing the practice of hunting. In the same vein, Section 144 of the Forest Law allows the administration to sell the seized perishable products by public auction. ${ }^{45}$ Section 142 of the same law provides that the sworn agents shall, upon the finding of the facts, seize the wrongly harvested products and the articles used to commit the offence and draw up a report. They exercise a right of action against offenders.

Under the system of administrative authorisation, the criminal law protection of wildlife reserves is "somewhat masked by the protection of administrative action" 46 exercised by officials of the Ministry of Forests. Through this mechanism of textual anticipation, the legislator incriminates offences against wildlife by establishing a presumption of risk with respect to certain human behaviours. This anticipation allows, at least ideally, the prevention of abusive infringements of protected species, but also, and above all, facilitates the incrimination procedure, especially through the insistence on the proofs of the offence. In this respect, it seems possible to conclude, that poor knowledge of environmental standards, even if it does not immediately cause damage to the wildlife environment, is likely to lead to the punishment of its perpetrator. This is how environmental offences are managed by the criminal law that ensures the protection of endangered species through monitoring and planning by the administration. In this regard, the application seems close to the repressive law of the environment through the severity of the means used ${ }^{47}$ to protect endangered fauna species.

Given that they are pronounced very rapidly by the administration because of their simplicity and especially the immediate knowledge of the infringement, administrative sanctions generally precede criminal penalties. Once pronounced, and when the

42 According to the provisions of Section 29 of Decree No. 95/466/PM of 20 July 1995.

43 Prabhu (1994: 669).

44 In the commission of an offence punishable by a fine of at least 3,000,000 FCFA.

45 Or by mutual agreement, in the absence of a bidder, by the competent administration, except for those that are dangerous or damaged.

46 D'Ambrosio (2015: 90).

47 Estupinan-Silva (2015: 26). 
measures they ordered enforced, or the lack of hunting permit regularised, criminal action is no longer necessary. But, on closer inspection, these measures are more regulatory than punitive. The punitive logic becomes secondary since the non-respect of these administrative measures may be subject to criminal sanctions.

In this regard, the law of 1994 sets up criminal sanctions for some offences committed in wildlife reserves in Cameroon and the penalties provided for are applicable without prejudice to confiscations, restitution, damages and remediation of the site as ordered by the administrative officials. These penalties are doubled in the event of recidivism or if it is a sworn officer of the competent administration or a judicial police officer with general jurisdiction who commit the corresponding offences, or if they are accomplices. This is without prejudice to the administrative and disciplinary sanctions. The penalties are also doubled for any hunting with the use of chemical or toxic products, violation of forest control barriers and in the event of a hit-and-run offence or refusal to comply with the injunctions of control officers. Furthermore, unauthorised traffic in a protected area is punishable with a fine of from 5,000 to 50,000 FCFA and/or imprisonment for ten days. ${ }^{48}$ Section 155 of the 1994 Law provides for a term of imprisonment of from twenty days to two years and a fine of from 50,000 to 200,000 FCFA or one of these sentences, against any person engaged in hunting without the required licence or permit. ${ }^{49}$ In addition, the sentences set out are in principle applied without a stay of execution or mitigating circumstances ${ }^{50}$ as provided for by criminal law. ${ }^{51}$

However, Cameroonian jurisprudence rather seems lenient against offenders and imposes very light sentences, often whimsical and reduced by mitigating circumstances and stay of execution. ${ }^{52}$ For instance, the Yabassi Court of First Instance, after finding the defendant guilty of slaughtering and moving around protected animals without a hunting permit, granted him mitigation circumstances. ${ }^{53}$ Similarly, the Court of First Instance of Ebolowa by Judgement No. 480/COR of 6 September 2011, sentenced the defenders, found guilty of illegally keeping fully protected animals and capturing Class A species without a capture permit, to two months imprisonment and 150,000 and 100,000 FCFA fine respectively. This stand of Cameroonian jurisprudence is in contradiction with the repressive environmental provisions, in particular,

Section 154 of law No. 94/01 of 20 January 1994 to lay down forestry, wildlife and fisheries regulations.

49 Section 91 and following of the law of 20 January 1994.

50 Section 87 of the framework law of 1996 on environmental management in Cameroon.

51 Section 54 and 94 of Cameroon's new Penal Code of 2016.

52 The Judicial decisions sanction the capture of Class A species without licence (cf. the Yabassi Court of First Instance, Judgement No. 43/COR of 4 November 2003), the marketing of Class $\mathrm{B}$ animals without collection permit or certificate of origin, the slaughtering of protected animals without a hunting permit, the detention and illegal marketing of panther skin, etc. 
Article 87 of the 1996 framework law. It is a position that is likely to encourage negligent or fraudulent behaviours or even the express violation of the law by offenders.

As it can be seen, repressive environmental law is multidimensional in nature.$^{54} \mathrm{It}$ makes the distinction between administrative offences and purely repressive offences. The purely repressive offences consist of acts or omissions relating to the destruction of wildlife species, depletion or management of natural resources. The penal legislator does not necessarily require a material element of the result. To this end, the infringement is established when the existence of a behaviour endangering the life of the protected animal species is proven. Thus, the Court of First Instance of Yaounde administrative centre found a defendant guilty of illegally detaining ivory tusks and marketing game trophies ${ }^{55}$ and sentenced him to a 30 -day suspended prison sentence and a fine of 100,000 FCFA. The same sentence was applied to a person convicted of possessing and selling elephant trophies. ${ }^{56}$

If at first sight, such a position seems to violate the principle of nullum crimen sine injuria as denounced by the doctrine. ${ }^{57}$ At the practical level it allows, however, for the rehabilitation of the object of the offence by annihilating the requirement of causality and result. ${ }^{58}$ Criminal liability requires criminal intent, ${ }^{59}$ but this intent is equated with gross negligence in environmental criminal law, for environmental crimes are not often isolated facts, but continuous facts where actions and omissions blend with a psychological aspect often linked to negligence rather than intent.

Wildlife liability may affect not only individuals but also legal entities. To this end, Article 150(1) of the law of 20 January 1994 states that: "Any individual or legal entity found guilty of violating the provisions of this law and its implementing instruments shall be liable and punishable in accordance with the penalties provided therefor". Thus, Cameroonian environmental law is concerned with the criminal enterprise and henceforth permits the inclusion of legal persons and administrative agents involved in the commission of an offence within the circle of responsibilities. ${ }^{60}$

Furthermore, in providing for offences for failure to comply with legal requirements, the legislator sets a presumption of knowledge of the rules against the offender and, at the same time, excludes the error of law as a defence and retains only the factual error or lack of diligence. This solution of environmental criminal law seems interesting since it allows for proactive action, before the realisation of any hindrance, so as to prevent reprehensible behaviours. ${ }^{61}$ Here, the penal legislator will not make the

54 Estupinan-Silva (2015: 26).

55 Yaounde Court of First Instance, Judgement No. 1201/CO of 17 December 2003.

56 Ibid.

57 Carraccioli (1994: 1013).

58 Minko-Ndongo (2015: 45).

59 Kalda (2014: 51).

60 Article 150 paragraph 2 the law of 20 January 1994.

61 It is an anthropocentric vision that considers environmental protection as a means of protection of the human interests and not as an intrinsically protected value by itself. 
reprehensible behaviour disappear, but rather try to make it as respectful as possible of the critical state of biodiversity in the wildlife reserves. Consequently, protection and liability may present an apparent contradiction. ${ }^{62}$ In fact, holders of permits or licences to hunt or slaughter protected species are exempted from the criminal responsibility, even when they capture an endangered species.

It is, however, regrettable that Cameroonian courts only marginally engage criminal actions against perpetrators of massive destruction of the wildlife. These jurisprudential hesitations may be indicators that could prompt legislative action for the acknowledgement of an autonomous place of repressive law within Cameroonian criminal law.

\subsection{An indispensable protection of biodiversity in wildlife reserves}

In order to preserve biodiversity in the wildlife reserves, the Cameroonian legislator has established a set of criminal rules to stop the threat of their impoverishment. Sustainable protection of species can only be guaranteed if living conditions are also guaranteed. In this respect, the preservation of the tropical fauna also implies the preservation of the living space of wild animals. It is within this perspective that, in defining the wildlife reserve, the legislator refers it to the natural habitat of species. ${ }^{63}$ The legislator has made a choice of a conservation policy of natural ecosystems and habitats and a policy of maintaining and restoring viable populations in their natural environment. ${ }^{64}$

Although not explicitly specified by the legislator, it is conservation in situ ${ }^{65}$ which implies monitoring and protection of the wildlife found in a given space and which is of a certain interest for man. This conservation, entails less $\operatorname{cost}^{66}$ than ex situ conservation $^{67}$ and extends to nearby zones to protected areas. This technique increases the limits of criminal law protection, by promoting sustainable and ecologically sound development. These areas are generally places where feed is available or that are suitable for nesting and mating. ${ }^{68}$ Article 154 of the law of 20 January 1994 provides that contacts with neighbouring populations of wildlife reserves should be as little as possible.

62 Tricot (2015: 145).

63 Article 2(7) of Decree No. 95/466/PM 20 July 1995 to lay down the conditions for the implementation of wildlife regulations.

64 Article 2 of the 1992 Convention on Biodiversity.

65 It is not clearly stated in the text that wildlife reserves would be the subject of the in situ conservation, but there is no indication to the contrary; and according to Article 9 of the Convention on Biodiversity, measures adopted for the ex situ conservation complement those taken for in situ conservation.

66 Gonmadje et al. (2015: 46).

67 Guideline No. 2004/35/CE, Appendix II, Article 1(d).

68 ITIO Directive for the Conservation and Sustainable Use of Biodiversity in Tropical TimberProducing Forests, Development Policy No. 17 OIBT/ITTO/UICN 20092. 
To this effect, any provocation of wild animals is forbidden. Similarly, freedom of movement is also restricted.

In addition, the legislator sets up buffer zones ${ }^{69}$ located at the periphery of wildlife reserves that enjoy the same criminal law protection as the overall biodiversity. The criminal law insists on the protection of endangered species and provides, to that effect, a set of measures that regulate all human activities likely to have an impact on them and their living environment. This is the case with the prohibition of bushfires and any activity that could affect, in one way or the other, the living environment of protected organisms within wildlife reserves. Indigenous and local populations cannot freely exercise their right of use on the preserved space. The exploitation of products of reserves is only allowed if it does not alter the course of forest productivity. The new Penal Code, in Articles 187, 187(1) and 227, as well as the law of 20 January 1994 in Articles 155 and 156 penalise fire, destructions and any other form of degradation. The penalty is doubled if the perpetrator or the accomplice is in a state of recidivism or belongs to the administrative body.

The protection of biodiversity in wildlife reserves seems essential insofar as it is necessary to protect the entire environment where the endangered species live. It is therefore important to provide an adequate response to environmental management as a whole by including all the components of the ecosystem because there is no sustainable development that does not take into account this essential fact, especially the one that wild flora and fauna are unpredictable natural elements. Forest degradation could have a negative impact on the communities that live within them and whose means of subsistence largely depend on products found in their living environment.

For this reason, the use of forest resources and space is subject to a strict legal framework that limits its duration and extent. Thus, all uses for economic purposes are subject to obtaining a permit from the forest administration and must comply with the objectives set by the latter. The law justifies this incursion into the private domain by ecological motivations, the imperative nature of which explains the necessity for the State to intervene, at the expense of the owner. Thus considered, the concessions authorising wildlife management are limited in time ( 15 years renewable once). They are also limited in space $(200,000 \mathrm{ha})$ and material extent of the right transferred to the licensee. The legislator also regulates the prerogatives of the populations resulting from the appropriation and use of lands, keeping only those that allow for biodiversity conservation. Some of these prerogatives regulated include the mutilation of protected species, grazing, logging, ${ }^{70}$ etc. The aim is to contribute to the protection of 
biodiversity by developing measures to regulate activities likely to have a negative impact on the survival of wild animal species ${ }^{71}$ and their natural environment. ${ }^{72}$

Despite the existence of all the aforementioned conservation measures with criminal penalties for non-performance, the state of degradation of wildlife reserves of Cameroon continues to worsen. It seems that economic interests are taking precedence over environmental considerations. This is because it is difficult to reconcile what cannot be reconciled, in other words, to optimise the exploitation of wildlife resources while taking into account the imperative of sustainable development, and especially to fight against poverty effectively. The helplessness of the administrative agents, if not their inability to rigorously react after each serious attack to the biodiversity, bears witness to this reality. Therefore, the effective enforcement of the environmental criminal law in force in Cameroon is far from being a priority. However, penal sanctions play a considerable preventive role in environmental matters, because as Plato recalled in the antiquity: ${ }^{73}$

He who cares to punish cleverly do not strike because of the past - what is done is done - but for anticipation of the future, so that neither the culprit nor the witnesses of this punishment be tempted to begin all over.

Repressive texts do set criminal sanctions against biodiversity offenders, but these texts are rarely applied to the intended extent. In any case, the lack of vitality of criminal law in environmental matters, and especially the side-lining of local residents in the drafting of criminal policy in the domain of biodiversity protection seems to explain the gap that still exists between the drafting of standards and their practical implementation.

A contrasted real application of repressive rules in the protection of biodiversity in wildlife reserves

Urbanisation, intensive exploitation of soils, mines and quarries, agriculture, the development of infrastructure ${ }^{74}$ and demographic explosion are all causes of destruction of the habitats of species and consequently of the biodiversity crisis. Indeed, the fundamentally anthropocentric vision of the world pushes men to place their interests over those of non-human entities, despite the repressive measures that can be taken to ensure the conservation of the latter. Thus, infringements on biodiversity are commonplace in spite of penal sanctions provided for to this effect by the legislator. Several factors can justify this situation including the ambiguous and limited nature of the

71 Prieur (2004: 8).

72 Despax (1980: IX 8).

73 Plato (1984: 39).

74 de Sadeleer \& Born (2004: 15). 
penal provisions that regulate activities in the wildlife reserves of Cameroon and their inadequacy with the contemporary environmental requirements.

\subsection{The ambiguity of repressive provisions for the protection of biodiversity in wildlife reserves}

A reading of the repressive provisions punishing offences committed in Cameroon wildlife reserves reveal, at first glance, a lack of cohesion and above all a lack of convergence between the various sanctions provided for in cases of violation. This is likely to generate conflicts of the laws and especially a competitive dynamic between the various texts that can be applied. The competition is necessary with regard to the transaction that is easily proposed by the administration ${ }^{75}$ since the 1996 framework law on environment provides that the public action shall cease when the perpetrator has fulfilled all the obligations resulting for him from the acceptance of the transaction within the time limit set. ${ }^{76}$ This competition results in the termination of criminal proceedings following the execution of administrative sanctions. The transaction replaces criminal prosecution, since it is implemented in their stead.

This distinguishing effect of criminal prosecution is all the more disconcerting as the environmental transaction has a very wide field of application in Cameroonian law. In fact, pursuant to Article 91(1) of the framework law of 1996, the administrations responsible for environmental management have full power to make a deal. ${ }^{77}$ Thus, it is possible for the administration to implement the transaction for any environmental offence provided for by the legislator. It should be noted that the Cameroonian legislator has not set any limit that would exclude the transaction for offences of particular gravity for the biodiversity either because of the consequences that they could engender, for example, the definitive extinction of a species protected or because of the modus operandi.

Owing to the fact that it allows a fine to be proposed to the offender, the amount of which may not be less than the minimum amount of the corresponding criminal fine, ${ }^{78}$ it seems obvious that the environmental transaction is repressive. This is especially so since the transaction is most often the concertation between the prosecution and the competent administrative authority. ${ }^{79}$ It allows the administration to propose a sanction of a punitive nature. The environmental transaction provides a simple, quick and inexpensive response to offences concerning biodiversity violations in wildlife reserves of

75 Mayer (2014: 523).

76 Section 146 and following of the law of 20 January 1994.

77 Also see the provisions of Articles 146 and 147 of law No. 94/01 of 20 January 1994.

78 Article 91 paragraph 2 of the framework law of 1996 on environmental management in Cameroon.

79 Perrier (2017: 2). 
Cameroon. However, it is important to know whether these transactional measures are effective and dissuasive enough to ensure the prevention of damage to biodiversity.

While it is undeniable that environmental transaction provides a repressive response to the offence on biodiversity, its effectiveness in preventing such harm is questionable. Indeed, the transaction is not dissuasive. This lack of deterrence should encourage the Cameroonian legislator to limit the recourse to transaction only to minor infringements. For more serious offences, including illegal hunting of endangered species, it would be preferable to resort to sufficiently severe criminal sanctions. It is possible that the mere threat of imprisonment can help to achieve the prevention goal as sought for in international standards.

Moreover, it is not always obvious to have sufficient coherence in the penalties provided for by the Cameroonian legislator. The Penal Code provides for stronger penalties, with heavier prison sentences than the specific texts applicable to wildlife reserves. Thus, Section 155 of the Penal Code provides for, apart from the fine, an imprisonment term of 20 days to two months for the felling of protected trees. Section 184 of the Penal Code penalises a degradation of public or classified property by imprisonment from one month to two years. The same applies to the burning and destruction of property for which the Forest Law provides a prison sentence of six months, while the Penal Code sets a prison sentence from three to ten years. More so, when cases are brought to court, flexible sentences are often applied to offenders. The Ebolowa Court of First Instance, for example, sentenced a defendant to only two months in prison and a fine of 150,000 FCFA for illegal detention of fully protected animals and the capture of Class A species without a permit.

The discrepancies between the various criminal penalties are due to the fact that the forestry law focuses on taxation to the detriment of penal rigour. In fact, the legislator favours the pecuniary nature of penalties in disregard of the deterrent impact that could have more severe incriminations on the behaviour of those that the penal norms target. For example, Article 75 of Decree No. 95/466/PM favours the confiscation and auctioning of products from poaching, to the benefit of the administration. In practice, this criminal policy implemented in environmental matters does not have the desired effect on offenders because the amounts allocated for damages resulting from the commission of wildlife offences are often derisory in relation to the gravity of the offence. Imposing fines as the only criminal sanction applicable in the event of a violation of repressive environmental provisions does not seem judicious insofar as it seems insufficient compared to the severity of damages on the environment. In some cases, damage are irreversible, such as the complete disappearance of the western black rhino from Cameroonian territory in 2011. ${ }^{80}$

Generally, many factors contribute to the degradation of biodiversity in Cameroon. The role that criminal legislation should play is to adopt means and instruments that

For research see Prouteau-Lagrot (2007: 80). 
can combat the daily delinquency that rages the wildlife reserves more effectively and promote the sustainable conservation of species and their habitat. An overhaul of criminal provisions in this domain seems urgent. Thus, in order to put an end to the profitability of environmental criminality and to strengthen the effectiveness of criminal responses, it seems essential that the state adopts sanctions that are equivalent to the gravity of environmental crimes. Penal sanctions should be defined according to the quality of the offenders and especially as regards the specificity of the offence. The individualisation of sentences would make it possible to apply the most appropriate sanction depending on the nature of the offence, the profile of the offender, the damage caused etc. ${ }^{81}$

\subsection{Obsolescence of repressive provisions for the protection of wildlife reserves}

In developing countries like Cameroon, local populations require opportunities to gain access to the resources which they need to survive. Environmental resources such as wildlife reserves often appear as a public utility that meets the criteria of non-exclusion. ${ }^{82}$ The use of such utility is in principle free and not subjected to any formality or authorisation. It is a recognised subjective right ${ }^{83}$ of local residents, that is justiciable ${ }^{84}$ and opposable to third parties. ${ }^{85}$

This right of use, however, is nevertheless regulated in wildlife reserves. Damage to preserved species is allowed only in cases of self-defence. ${ }^{86}$ Articles 82 and 83 of the law of 20 January 1994 exempt any person who kills or injures a classified animal in self-defence without provoking it from criminal liability. Similarly, the administration can proceed to controlled push-backs, when animals pose a danger to people or property. Apart from these protective measures, local populations whose survival depends on forest resources have largely been ignored by legal provisions. ${ }^{87}$ The right of use of these communities within protected areas is subject to limitations (e.g. Article 5 of the decree of 20 July 1995). ${ }^{88}$ These limitations at times generate conflicts between the

81 Fouchard \& Neyret (2015: 415).

82 Bacache-Beauvallet (2008: 35).

83 Ibid.

84 Favoreau (2008: 1228-1230).

85 Nonaros (1996: 216); and Dabin (1952: 80-92).

86 Nevertheless, the person must prove the state of self-defence within 72 hours. If not they are liable to another offence punishable by a fine of 5,000 to 20,000 francs and/or 20 days to two months in prison (Article 155 of the law of 1994).

87 The legislator has voluntarily excluded the riparian population from the circle of people to be protected, even as the notion of environment is far from being an abstraction, but rather considered in its entirety.

88 These are the rights granted to the riparian population "to harvest all forest, wildlife and fisheries products freely for their personal use, except the protected species". See Article 8 of the law of 1994. 
respect of the law on the one hand and ancestral practices on the other. ${ }^{89}$ Indeed, the penalties imposed on members of indigenous communities often increases the hostility of these groups populations against the criminal law. In one case, for example, the Dschang Court of First Instance sentenced the defendants convicted of destroying a protected area to a six-month suspended prison sentence and a fine of 50,000 FCFA. By doing so, the court ignored the fact, that the defendants were not only poorly educated but also their state of necessity when exploiting environmental resources.

The local population's distrust of the law is exacerbated by the granting of exploitation rights to foreigners. An example is a case in the northern region, where the State transferred 19 out of 28 hunting areas to foreigners ${ }^{90}$ to the detriment of local populations' pastures.

The exclusion of local populations from responsible protection of protected areas is one of the major flaws of the policy of conservation of wildlife biodiversity in Cameroon. Only participatory inclusion through the involvement (and not the exclusion or taxation) of local populations in the organisation, valorisation and management of wildlife reserves, can reduce the threat of extinction of vulnerable species. Residents of wildlife reserves live in a precarious situation, which requires improved dialogue and the consideration of their existential problems. The State should rather grant these groups subsidies to foster their enthusiasm about preserving the reserves linked to their ancestral heritage In addition, such grants could develop profitable alternative activities that enable local populations to take care of their most vital need and at the same time contribute to biodiversity protection in the form of payment for environmental services. ${ }^{91}$

Cameroonian environmental law is also drifting away from its international environmental law obligations. Despite a cautious introduction of innovative elements through the incorporation of international principles developed in 1992 in Rio, Cameroon's repressive laws attempt to make wildlife resources contribute to economic development at the cost of ecological, social and cultural concerns. Far from being a protective law, Cameroon's environmental criminal law largely focusses on use and exploitation of natural resources, providing economic privileges over sustainable ecosystems.

89 Barume (2004: 14).

90 Which moreover carries three parks of 730,000 ha and a vast ZIC of more than 2,000,000 ha. It is important to note that in 1986, there were 15 ZICs in the North for a total area of 729,390 ha. In 1996, this number rose to 27 and 28 in 1998. These 28 ZICs have a precise distribution: 23 are leased to hunting guides, three are managed by the state, one is allocated to the Lamido of Rey Bouba and one is intended for experimentation of a game-ranch.

91 Payments for environmental services (PES) are incentives that provide compensation in exchange for adopting practices that are conducive to the preservation of environment. They are based on contractual constructions that may involve private actors (landowners, companies, associations...) and public actors (the state, local authorities...). 
While for instance the precautionary principle under the Rio Declaration was incorporated in various national texts (e.g. Article 9 of the framework law of 1996 on environmental management), Cameroon's forest criminal law is still contrary to principles of rational management of wildlife resources. In many cases, the forest administration continues to use unsustainable methods geared towards generating income for the national economy. The prescribed hunting season, for example, partially overlaps with the gestation periods for female animals, thereby promoting the interests of hunters over those of wildlife.

However, a more efficient management of protected areas should be adapted to conditions which best foster the protection of biological diversity. Protected sites could serve as an experimental approach to enhance the management, reproduction and protection of endangered species. Research students from different universities in Cameroon could benefit from scholarships to carry out field studies in the company of guards working in the reserves. ${ }^{92}$ This would foster scientific knowledge on the one hand and strengthen a more cautious approach to the management of biodiversity on the other. Investigating commercial activities' impacts on forests and wildlife are equally essential. Although the implementation of certain environmental protection measures is costly, these could be funded by increasing returns from tourism. All of the aforementioned would contribute to an improved wildlife reserves governance in Cameroon.

\section{Conclusion}

There are many expectations regarding the repression of damages on biodiversity in Cameroon's protected areas. One of them is to enshrine ecocide ${ }^{93}$ crimes in environmental penal law envisaging punitive damages. ${ }^{94}$ Environmental offences are often lucrative in nature, committed voluntarily in the interest of commercial profit. In the same light, repressive biodiversity protection policies should not only consider the degradation of ecosystems but also the vulnerabilities of the poorest populations. Criminal law protection of biodiversity in wildlife reserves should be an ethical duty towards the threatened future and survival of both man and ecosystems. ${ }^{95}$ As a proverb puts it so well, "when the last tree has been cut down, the last fish caught, the last river poisoned, only then will we realise that one cannot eat money."

92 In this sense, impact studies carried out by these reserves would enable MINFOF (the supervisory Ministry) to locate the difficult sectors and set up integrated study scenarios. Indeed, it is impossible that, on the field, MINFOF officials be the judge and party at the same time. The impact studies have the advantage of encouraging planning that goes along with monitoring and evaluation of the different projects initiated.

93 This involves the massive destruction of flora and fauna, as well as the implementation of any action that would cause an ecological disaster.

94 Lambert-Faivre (1998).

95 Thibierge (2013: 577). 


\section{References}

Albertini, P (2015) La crise de la loi: déclin ou mutation?

Bacache-Beauvallet, M (2008) "Marché et droit, la logique économique du droit de l'environnement" 4 Pouvoirs 35-47.

Barume, AK (2004) Cadre juridique et coutumier pour la protection des droits des peuples indigènes et tribaux (autochtones) au Cameroun: points d'entrée, 2éme version initiale.

Beccaria, C (1856) Des délits et des peines.

Bille, R \& R Picard (2007) La conservation de la biodiversité dans le cadre de l'aide au développement: une synthèse critique, at <https:/www.iddri.org/sites/default/files/import/publications/ an_0701_bille\%26pirard_biodivetdevpmt.pdf> (accessed 20-7-2018).

Cans, C \& C de Klemm (1998) "Un cas d'irréversibilité : l'introduction d'espèces exogènes dans le milieu naturel" RJE 119.

Carraccioli, I (1994) “La protection de l'environnement en droit pénal italien” 65 RIDP 1013.

Clay, J (2003) “Arbitrage et droit de l'environnement" 149 Gazette du Palais 10.

Cornu, G (2011) Vocabulaire juridique $9^{\text {th }}$ ed.

Dabin, J (1952) Droit subjectif.

D’Ambrosio, L (2015) "Vers un droit pénal commun de l'environnement: critères et techniques d'incrimination" in L Neyret (ed.) Des éco-crimes à l'écocide, le droit pénal au secours de l'environnement 90.

Deffairi, M (2016) "Le recours aux instruments économiques; facteur de modernisation et/ou de simplification du droit de l'environnement" in I Doussan (ed.) Les futurs du droit de l'environnement: simplification, modernisation, régression? 176.

de Sadeleer, N \& CH Born (2004) Droit international et communautaire de la biodiversité.

Estupinan-Silva, R (2015) "Report on the Ecocide Project" in L Neyret (ed.) Des éco-crimes à l'écocide, le droit pénal au secours de l'environnement 66.

Favoreau, L (2008) Droit constitutionnel.

Fossier, T (2017) "La nécessité et l'efficacité de la sanction pénale en droit de l'environnement" 12 Energie-Environnement-Infrastructures 11.

Fouchard, I \& L Neyret (2015) “35 propositions pour mieux sanctionner les crimes contre l'environnement” in L Neyret (ed.) Des éco-crimes à l'écocide, le droit pénal au secours de l'environnement 415 .

Fritz-Legendre, M (1998) "Biodiversité et irréversibilité" 96 RJE 79-100.

Gonmadje, CF, JB Donfack \& J Kengue (2015) L'état des ressources forestières mondiales - Cameroon National Report.

Kalda, G (2014) Contrat et droit pénal Dissertation Master II, University of Yaounde II.

Kamto, M (1996) Droit de l'environnement en Afrique.

Lambert-Faivre, Y (1998) “L'Ethique de la responsabilité” RTD civ 1-22.

Ly, I \& M Ngaide (2008) Droit de l'environnement au Sénégal. 
Martin, G (1995) "La notion de responsabilité en matière de dommage écologique" Droit et environnement : propos pluridisciplinaires sur le droit en construction PUAM 135.

Martin, G (1992) “Dommage écologique en droit interne, communautaire et comparé” Economica 11.

Minko-Ndongo, MN (2015) La problématique de la protection juridique des réserves de faune au Cameroun, Dissertation, Master II, University of Yaounde II.

Nguiffo, S \& M Talla (2010) "Législation relative à la faune sauvage au Cameroun: entre usage locaux et perception légale" 236(61) Unasylva 14-18.

Nguiffo, S (2001) “Cameroun: la réserve de la faune du DJA” Peuples autochtones 197-216.

Nonaros, M (1996) "L'évolution récente de la notion de droit subjectif” RTD civ 216.

ITTO / International Tropical Timber Organization (2009) Guidelines for the conservation and sustainable use of biodiversity in tropical timber production forests policy development No. 17 OIBT/ITTO/UICN 2.

Ost, F (1995) “La responsabilité, fil d'Ariane du droit de l'environnement” Droit et société 287.

Perrier, JB (2017) "La répression des infractions environnementales, à la recherche de sanctions proportionnées, efficaces et dissuasives" 12 Energie-Environnement-Infrastructures Dossier spécial 1.

Plato (1984) Euvres complètes Tome III Les belles lettres.

Prabhu, M (1994) "Rapport général. Les atteintes à l'environnement: problèmes de droit pénal général” 65 RIDP 663-669.

Prieur, M (2003) "Vers un droit de l'environnement renouvelé" RJE 130-139.

Prieur, M (2005) "Les droits nouveaux" AJDA 1160.

Prouteau-Lagrot, I (2007) Probable extinction du Rhinocéros Noir de l'Ouest (Diceros bicornis longipes) Etude de terrain 2006 au Nord Cameroun Thesis National Veterinary School, Toulouse.

Remond-Gouilloud, M (1989) Du droit de détruire: essai sur le droit de l'environnement.

Tchindjang, M, SA Abossollo, J Armathée \& VF Menga (2006) "Les difficultés de développement de l'écotourisme dans les aires protégées du Cameroun" 26(2) Boletim Goiano de Geografia 1247.

Thibierge, C (2013) “Avenir de la responsabilité, responsabilité d'avenir” RTD civ 577.

Tricot, J (2015) "Eco-crimes et écocide: quels responsables" in L Neyret (ed.) Des éco-crimes à l'écocide, le droit pénal au secours de l'environnement 145.

Triplet, $\mathrm{P}$ (2009) Manuel de gestion des aires protégées d'Afrique francophone.

Trousse, PE (1956) Les Novelles - Droit pénal Vol. 1(1).

Tunc, VA (1977) “Un droit en miettes” XXII La responsabilité, Archive de philosophie 31-35.

Wafo Tabopba, G (2008) Les aires protégées de l'extrême nord Cameroun entre politiques de conservation et pratiques locales Thesis Orléa. 
